\title{
THE EFFICIENCY OF SELECTIVE TIDAL STREAM TRANSPORT IN GLASS EEL ENTERING THE GIRONDE (FRANCE)
}

\author{
L. BEAULATON, G. CASTELNAUD
}

Cemagref, unité Ecosystèmes estuariens et poissons migrateurs amphihalins, 50, avenue de Verdun, 33612 Cestas Cedex, France.

E-mail : laurent.beaulaton@bordeaux.cemagref.fr

E-mail : gerard.castelnaud@cemagref.fr

Reçu le 19 août 2004

Accepté le 13 octobre2005

Received August 19, 2004

Accepted October 13, 2005

\section{ABSTRACT}

Traditional estimation of migration speed is based on telemetry or marking of individual fish. Only a few numbers of fishes (or batches) are followed, often over short periods of time. We propose a method based on capture data from the professional fishery. It is applied to glass eel (Anguilla anguilla) in the Gironde basin (France).

Migration speed is estimated using 2 methods: a rough method based on the analysis of seasonal abundance peaks for two métiers and a more precise method of cross-correlation, which compares speeds between several fishing areas. The methods are coherent and lead to mean migration speed ranging from 3 to $4 \mathrm{~km} /$ day.

We define an index of efficiency of migration using selective tidal stream transport (STST efficiency index) as the ratio of the observed migration speed to the potential speed (flood tide current speed and swimming speed). For the glass eel in the Gironde basin this index ranges between 0.15 and 0.19 . The glass eel behavior, which can explain this low value, is reviewed.

Our STST efficiency index can be successfully applied for many fish or crustaceans using selective tidal stream transport. It can also be used for one species to compare results obtained on different basins.

Key-words: Migration speed, sequential fishery, cross-correlation, selective tidal stream transport, glass eels, Anguilla anguilla, STST efficiency index.

\section{EFFICACITÉ DE LA MIGRATION DES CIVELLES ENTRANT DANS LE BASSIN DE LA GIRONDE EN UTILISANT UN TRANSPORT SÉLECTIF TIDAL}

\section{RÉSUMÉ}

Les méthodes traditionnelles d'estimation de la vitesse de migration reposent sur la télémétrie ou les techniques de marquage. Seulement un nombre restreint de poissons (ou lots de poissons) sont ainsi suivis, souvent sur un temps court. Nous proposons une méthode basée sur les données de capture de la pêcherie professionnelle. Elle est appliquée au cas de la migration de la civelle (Anguilla anguilla) dans le bassin de la Gironde (France). 
La vitesse de migration est estimée grâce à deux méthodes: une méthode grossière basée sur l'étude des pics saisonniers d'abondance de deux métiers de pêche ; une méthode plus précise utilisant les corrélations croisées qui permet de comparer des vitesses de migration entre plusieurs zones de pêche du bassin. Les résultats des deux méthodes sont cohérents et conduisent à une vitesse moyenne de migration de l'ordre de 3 à 4 km/jour.

Nous calculons un indice d'efficacité de la migration utilisant le transport sélectif tidal (STST efficiency index) qui est la vitesse réelle des civelles divisée par une vitesse potentielle (la somme de la vitesse des courants de flot et de la vitesse de nage). Pour le bassin de la Gironde, cet indice est compris entre 0,15 et 0,19. Les comportements de la civelle qui peuvent expliquer ces faibles valeurs, sont passés en revue.

Notre indice et nos méthodes peuvent être employés pour de nombreuses espèces de poissons et de crustacés qui utilisent le transport sélectif tidal. II peut également être utilisé pour une espèce donnée pour comparer les résultats obtenus sur différents bassins.

Mots-clés: Vitesse de migration, pêcherie séquentielle, corrélation croisée, transport sélectif tidal, civelle, Anguilla anguilla, STST efficiency index.

\section{INTRODUCTION}

An animal using selective tidal stream transport (CREUTZBERG, 1961; ARNOLD, 1974): (i) drifts in the water during favorable tides and (ii) settles at the bottom during unfavorable tides. This mechanism was described for fishes and crustaceans (WEIHS, 1978; CASTONGUAY and GILBERT, 1995; GIBSON, 1997; FORWARD et al., 1998; FORWARD et al., 2003).

European eels (Anguilla anguilla $(\mathrm{L}$.$) ) reproduce in the Sargasso Sea and colonize$ continental area (Europe and northern Africa) in their glass eel stage. Since the beginning of the twentieth century it is known that glass eels use flood tide currents in estuaries to migrate upstream (SCHMIDT, 1906; BERTIN, 1951). CREUTZBERG (1958) demonstrated with fishing experiments that glass eels use the flood tide current to migrate from North Sea to the freshwater. GASCUEL (1986) considered the glass eel migration like a simple use of the water-movement and called it "flow-carried migration". The general mechanism of "selective tidal stream transport" has been confirmed by studies in situ and ex situ on European and American eels (CREUTZBERG, 1961; MCCLEAVE and KLECKNER, 1982; MCCLEAVE and WIPPELHAUSER, 1987; WIPPELHAUSER and MCCLEAVE, 1987).

Very little is known about the efficiency of selective tidal stream transport. GASCUEL (1987a) used mark-recapture techniques, and showed that only $10 \%$ of glass eels use the full flood tides, covering a distance equal to the flood tide current. Most glass eels only partially use flood tide currents. Some glass eels go faster than the flood tide current. Glass eels can both be carried and swim during migration. We propose to use effective migration speed to evaluate the efficiency of this mechanism.

Two major tools can be used to evaluate migration speed of individual fish: telemetry (see THORSTAD et al., 2002) which monitors individual movement directly and mark-recapture techniques (see for example SHERIDAN and CASTRO MELENDEZ, 1990) which yields indirect estimates of the time of transit and the distance covered. Considering the small size of glass eel, telemetry is not feasible. The mark-recapture technique can be efficient in small areas (TZENG, 1984; GASCUEL, 1987a) but not in large rivers like the Garonne, because of the unrealistically high number of marks required (CANTRELLE, 1984). However, tracing sequential peaks in the catches of a series of spatially separated fisheries yields an alternative estimation method. We focus on the migration of European glass eel in the Gironde (France). 
We propose a quantitative estimator of the efficiency of selective tidal stream transport. We first estimate mean migration speed of glass eels in the Gironde basin from catches, using the time-lag between migration-peaks in neighboring river sections; secondly, we apply cross-correlations between the time series of catches. An estimator of the efficiency of selective tidal stream transport is derived.

\section{MATERIAL AND METHODS}

\section{Study area}

The tidal part of the River Garonne (Figure 1) is called "the Gironde basin" (CASTELNAUD et al., 2001). The distance between the sea and the tidal limit is approximately $160 \mathrm{~km}$. The Gironde basin is divided into: the Estuary $(\mathrm{E})$, which extends between the sea limit and salt limit $(73 \mathrm{~km})$ and the tidal river $(\mathrm{R})$ between the salt limit and the tidal limit. The tidal river comprises the River Garonne $(85 \mathrm{~km})$ and the River Dordogne $(75 \mathrm{~km})$ with its tributary, the River Isle $(31 \mathrm{~km})$. We determine four fishing areas in the Estuary (from E1 to E4) and three fishing areas in the tidal river (from R1 to R3).

\section{Data}

The glass eel is a juvenile stage of the European eel. It is targeted specifically by fishermen during its anadromous migration. The fishing season lasts from November to April. "Season 1999" indicates the fishing season starting in fall 1998 and ending in spring 1999.

Three métiers (fishing techniques) are distinguished: pibalour (large push net) in the Estuary (E1 to E4), tamis (scoop net) and drossage (small push net) in the tidal river (R1 to R3).

Data were collected from cooperating professional fishermen between 1978 and 1999. In 1997 and 1999, obligatory logbooks completed the data for drossage fisheries. Catch data were collected for each fishing zone over varying time periods (season, month, two-week period, day or fishing operation) and classified into quality levels, indicating the availability of effort information and the reliability of the data. We selected best quality data per day or per fishing operation (for more details, see CASTELNAUD et al., 2001).

Water temperatures were derived from the Blayais nuclear power plant (BNPP) (Figure 1). In the Loire (DESAUNAY et al., 1987), water temperatures below $6^{\circ} \mathrm{C}$ limit glass eel migration. We did not exclude low temperature data at forehand.

\section{Methods}

We estimated migration speed by two methods: seasonal abundance peaks and cross-correlations. Both methods are based on the variation in the catch per unit of effort in the fisheries, and the time lag herein between areas. This time lag is assumed to correspond to the time required to migrate from one to another area. Mean migration speed is then estimated by the ratio of true distance and time lag. All catches were assumed to originate from the center of each fishing area (Figure 1).

\section{Seasonal abundance peaks}

We used CPUE per tide month calculated with Generalized Linear Models (GLM) applied to the fishery data for the period 1978-1999. For each metier, the GLM is written:

$$
\text { CPUE }+0.1 \approx \text { season }+ \text { tide month }+ \text { tide }+ \text { fisherman }+ \text { season } \times \text { tide month }
$$

We use the GENMOD procedure of SAS (SAS, 2000) with a log-link and a gamma distribution. We add 0.1 to the CPUE data to avoid problem with zero-capture and log link. We choose 0.1 because this value is smaller than the mean CPUE. Zero-capture represents 


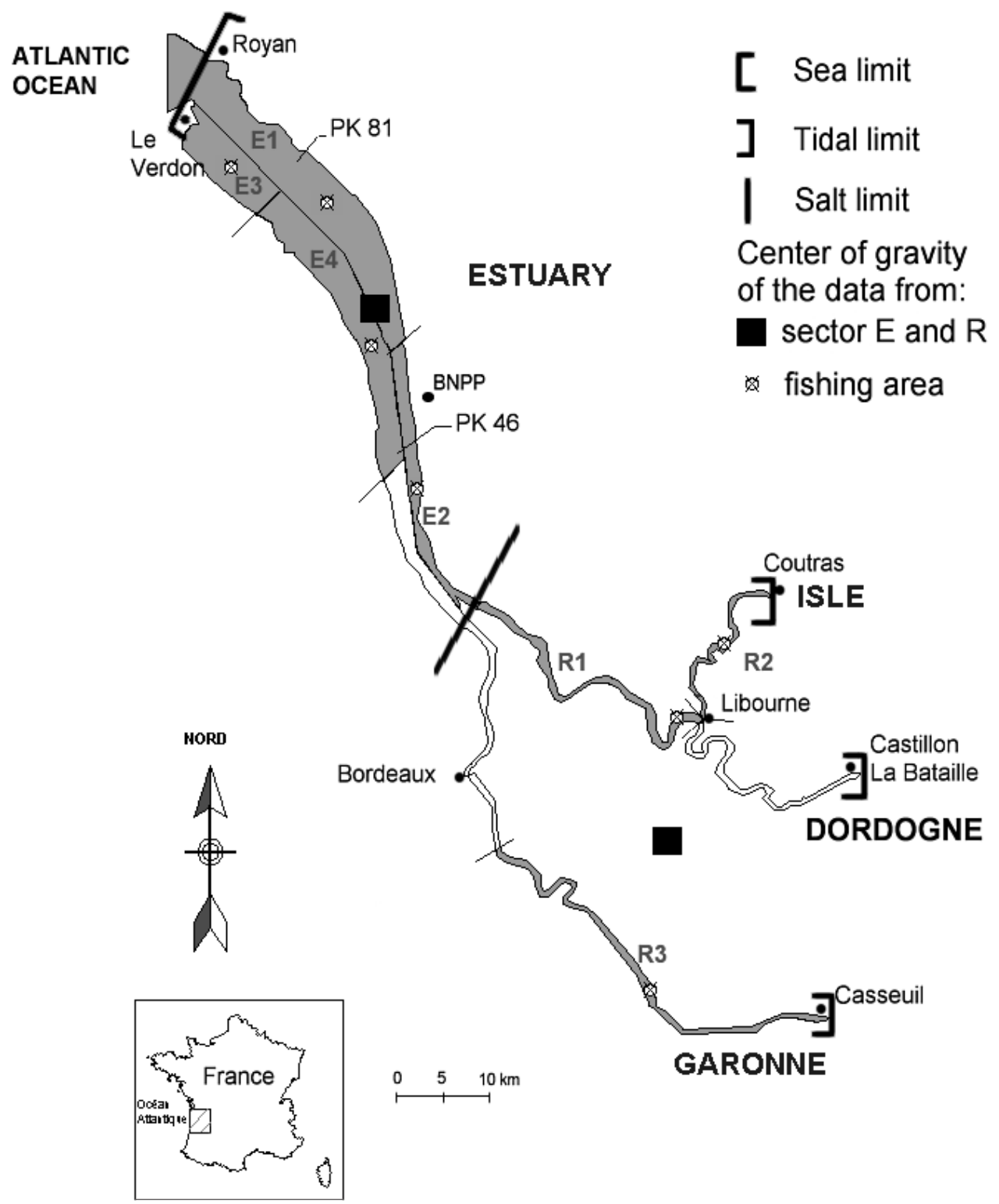

Figure 1

Map of the Gironde basin.

Figure 1

Carte du bassin de la Gironde.

only $2 \%$ of our data (429/18 878 data). The "season" effect represents the inter-annual variation of abundance. The "tide" effect is related to variations in tide coefficient. The "fisherman" effect takes into account the variation of fishing power between fishermen.

The "tide month" effect is based on a tide calendar. This is the equivalent of a civil month (January...) in a tidal calendar (Table I). The number of days in a complete tide month range from 27 to 30 days. This effect is supposed to characterize the inter-tide month evolution during a season. We calculated mean CPUE per tide month with the LSMEANS option of GENMOD procedure (SAS, 2000), for the pibalour and the tamis. We 
interpoled this mean per tide month using a cubic spline function (EXPAND procedure) to determine the maximum of CPUE. The time of transit of glass eels from Estuary to tidal river is given by the lag between the maximum of CPUE of the pibalour in the Estuary and the tamis in the tidal river.

\section{Table I}

Correspondence between civil dates and tide month.

\section{Tableau I}

Correspondance entre les dates civiles et les mois marée.

\begin{tabular}{|l|c|c|c|c|c|c|c|c|}
\cline { 2 - 9 } \multicolumn{1}{c|}{} & \multicolumn{7}{c|}{ Date of beginning of tide month } \\
\cline { 2 - 10 } \multicolumn{1}{c|}{} & $\mathbf{1}$ & $\mathbf{2}$ & $\mathbf{3}$ & $\mathbf{4}$ & $\mathbf{5}$ & $\mathbf{6}$ & $\mathbf{7}$ & End of $\mathbf{7}$ \\
\hline Earliest & 02 oct. & 28 oct. & 23 nov. & 27 dec. & 23 jan. & 25 feb. & 25 mar. & 22 apr. \\
\hline Mean & 05 oct. & 03 nov. & 03 dec. & 02 jan. & 01 feb. & 02 mar. & 21 mar. & 27 apr. \\
\hline Latest & 12 oct. & 10 nov. & 11 dec. & 10 jan. & 09 feb. & 10 mar. & 08 apr. & 30 apr. \\
\hline
\end{tabular}

\section{Cross-correlation}

\section{- Constitution of series of cpue}

The characteristics of the drossage (tidal river) and pibalour (Estuary) techniques are similar enough to allow a comparison of CPUE. The seasons 1997 and 1999 was chosen because of the availability of data. They represent a cold season (1997 - 12 days below $6^{\circ} \mathrm{C}$ ) and a temperate season (1999-0 days below $\left.6^{\circ} \mathrm{C}\right)$. We calculated a mean CPUE for each day and each fishing area. We used a weighted moving average of order 5 (2 days before and after) to complete missing values if they did not exceed 2 consecutive days. The weight (wj) was given by the equation (1), $\mathrm{m}$ representing the number of days before and after $\mathrm{j}$ (here $\mathrm{m}=2$ ). We thus obtained series of daily CPUE for each fishing area. Some of them had discontinuities; only the longest series were kept ( $>30$ days) (Figure 2).

$$
w_{j}=\frac{m+1-|j|}{\sum_{k=-m}^{m} m+1-|k|}
$$

We obtained 7 series per season (1 per fishing area) for 2 seasons (1997 and 1999).

We used the Pearson correlation coefficient of the CORR procedure of SAS (SAS, 2000) to estimate the correlation between two lagged series. A Student test was used to evaluate the significance of the correlation. The trend was extracted with a moving average because the series had to be stationary (LEGENDRE and LEGENDRE, 1979). The tide strongly influences the abundance of glass eels (LOWE, 1950; ELIE, 1979; SORENSEN and BIANCHINI, 1986; ROCHARD, 1992; CICCOTTI et al., 1995). For series with periodic component, LEGENDRE and LEGENDRE (1979) recommended to use a moving average of order of the wave-length (15 days in the case of tide). Equation (1) with $\mathrm{m}=7$ was used. All the lag-values between two fishing areas, leading to positive correlations with a significance level of $10 \%$ were retained.

- Choice of time of transit

Several postulates allowed us to force the system to select times of transit and to give coherence to the results. Firstly, we chose the times of transit that were found for both the seasons 1997 and 1999. Secondly, a time of transit had to be found both directly 


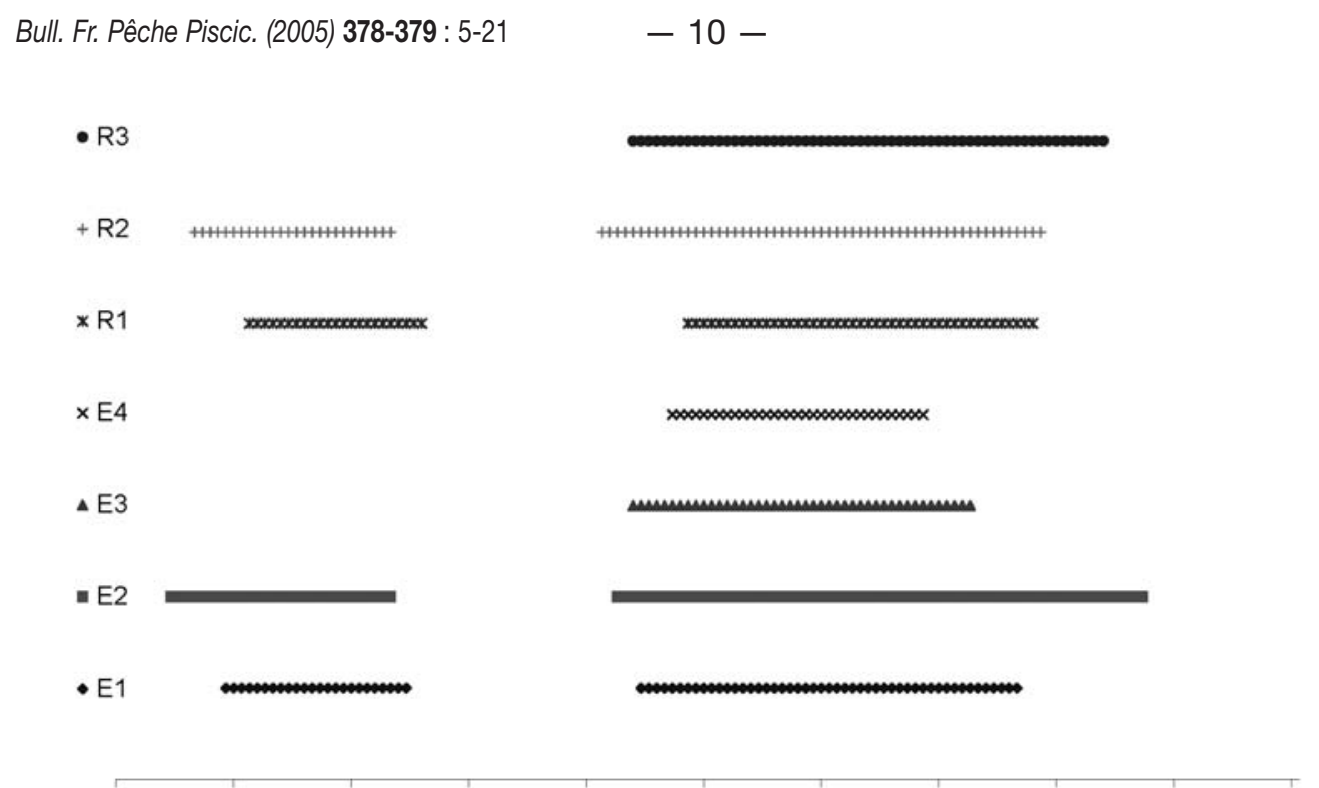

$\begin{array}{lllllllllllllll}15 / 11 / 96 & 30 / 11 / 96 & 15 / 12 / 96 & 30 / 12 / 96 & 14 / 01 / 97 & 29 / 01 / 97 & 13 / 02 / 97 & 28 / 02 / 97 & 15 / 03 / 97 & 30 / 03 / 97 & 14 / 04 / 97\end{array}$

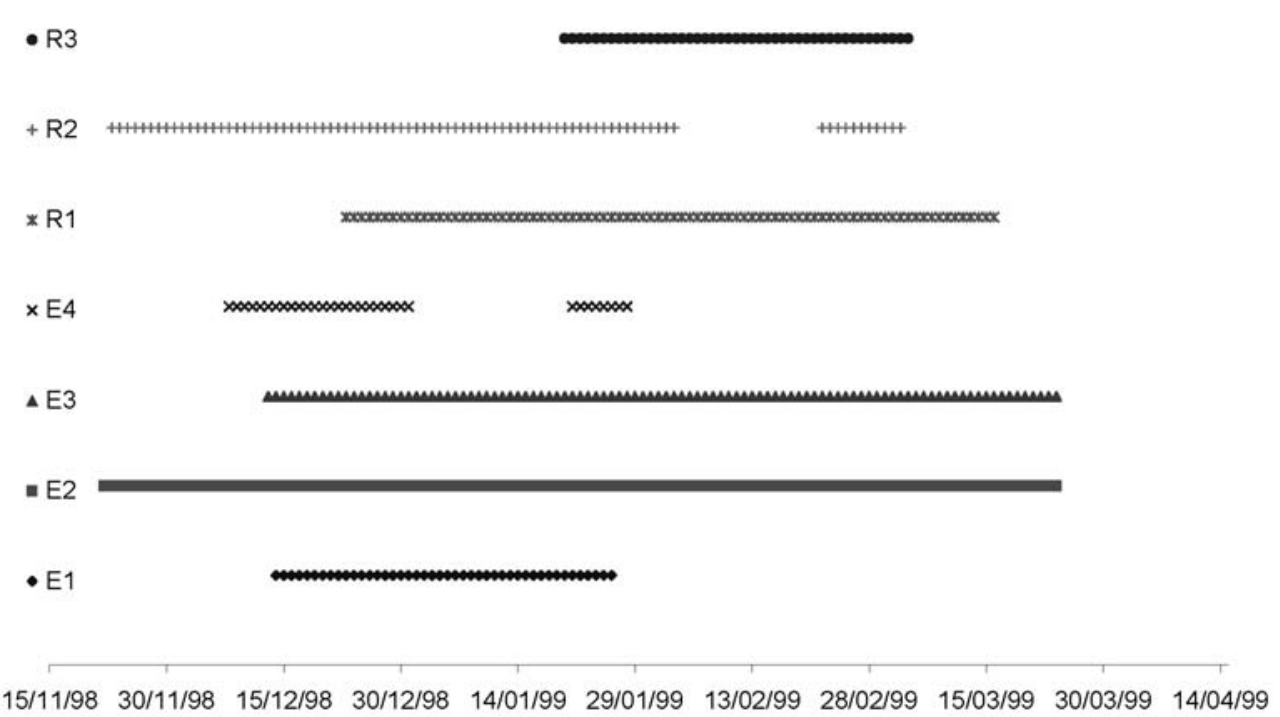

\section{Figure 2}

CPUE available per areas for season 1997 (upper panel) and 1999 (lower panel).

Figure 2

CPUE disponibles par zone pour la saison 1997 (haut) et 1999 (bas).

(lag value) and indirectly. For example, the time of transit between E1 and E2 was found either with the cross-correlogram between E1 and E2 or by subtracting time of transit found between E1/R1 and E2/R1. Thirdly, the time of transit E1/E2 had to be lower than or equal to the time of transit E1/R1, because the glass eels are supposed to move from downstream to upstream.

Efficiency of the migration using selective tidal stream transport

The efficiency of the migration using selective tidal stream transport (shorten in STST efficiency index) will be deduced from the ratio between observed glass eel speed and 
tide current speed plus swimming speed. As glass eels have weak swimming capacities (TSUKAMOTO et al., 1975; MCCLEAVE, 1980), we considered that the movement of glass eels in tidal part is mainly dependent of the flood tide current. Thus the index is simplified here in real speed divided by tide current speed. To solve the difficulty of calculating the flood tide current, we used the individual-based simulator "SEGPA civelles" (LAMBERT, 2005), which estimates, for mean conditions of tide and river discharge, the speed of a virtual glass eel optimally using flood tide currents, that is: being transported by water during the totality of the flood tide and sticked at the bottom during the ebb tide.

Finally, the STST efficiency index has been obtained by dividing the estimated speed of the real glass eels by the speed of the optimal virtual glass eel (assimilated to tide current speed). If this index is close to 1 , glass eels are very efficient; if this index is definitely lower than 1, glass eels make an under-optimal use of the flood tide currents; when this index is higher than 1, glass eels are upper-optimal, and in this case, the use of flood tide current cannot totally explain glass eel migration.

\section{RESULTS}

\section{Migration speed}

\section{Peak of abundance}

The GLM and all effects included are highly significant $(p<0.0001)$ and the reduction of deviance of the model is about $43 \%$.

The results of the interpolation by spline of CPUE per tide month obtained with GLM are given in Figure 3. Both metiers (pibalour and tamis) show a bell-shaped evolution

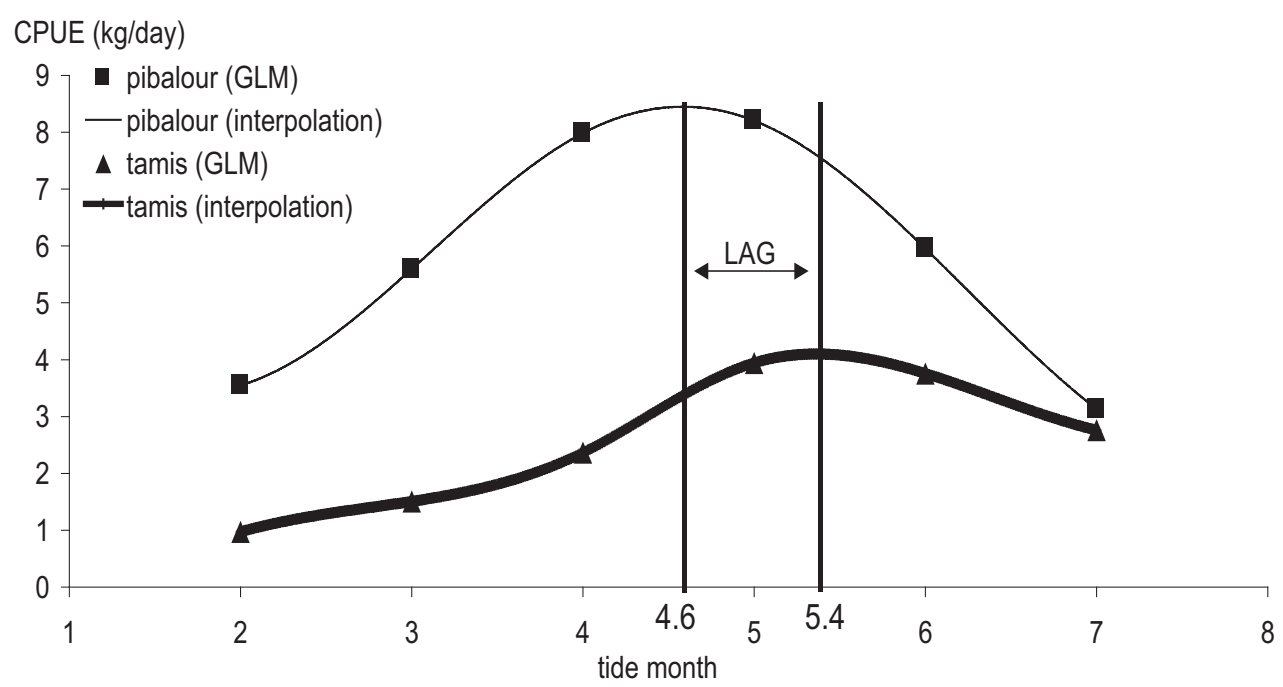

Figure 3

Raw results (Ismeans) of GLM (point) and interpolation by spline of CPUE per tide month (curve) obtained for pibalour (large push net in Estuary) and tamis (scoop net in tidal river).

Figure 3

Résultats bruts (Ismeans) des GLM (point) et interpolation par spline des CPUE par mois " marée " (courbe) obtenu pour le pibalour (estuaire) et le tamis (zone mixte fluviale). 
of CPUE. The maximum of abundance is situated for the pibalour at (tide month) 4.58, corresponding with mid or end of January, and for the tamis, at 5.36, corresponding with mid or end February. This suggests that the lag between the maximal abundances is about 0.8 tide month, which corresponds to approximately 23 days. The distance between the Estuary (pibalour) and the tidal river (tamis) is about $80 \mathrm{~km}$. A mean migration speed of $3.5 \mathrm{~km} /$ day is deduced.

A water temperature of $6^{\circ} \mathrm{C}$ was considered as a limiting factor. During the $1990 \mathrm{~s}$ only two seasons (1991 and 1992) include long period of cold-water temperature (22 and 20 days below $6^{\circ} \mathrm{C}$ respectively) and two seasons (1997 and 1998) have a short period of cold water temperature (12 and 3 days below $6^{\circ} \mathrm{C}$ respectively). During the six other seasons the water temperature never decreases below the threshold of $6^{\circ} \mathrm{C}$.

\section{Cross-correlations}

Figure 4 (upper panel) presents an example of raw data (CPUE and temperature) for the area E2 and R1 in 1997. These are two adjacent areas with long series. We can see the large variations of CPUE. At the beginning of January 1997, there were no fishing activity because of too low temperature of the water $\left(<6^{\circ} \mathrm{C}\right)$. Following this cold period CPUE increase progressively and did not show any sign of glass eels accumulation due to low temperature. Figure 4 also shows the trends extracted from these series using moving average. Both series peak during February and in March for $\mathrm{R} 1$ series.

The difference between raw data and trend give the residuals (Figure 4, lower panel). The $\mathrm{R} 1$ residuals are lagged of 13 days to emphasize the correlation between the series E2 and $\mathrm{R} 1$. With this lag, great positive or negative residual occur simultaneously. The choice of this lag of 13 days is the result of the observation of the cross-correlogram between the series E2 and R1 (Figure 5). One can see that correlation becomes significant for a lag of 12, 13 and 24 days. Cross-correllogram for season 1999 confirms this observation. We retain 13 days also because series E1/R1 and E1/E2 are correlated with a lag of 22 days and 9 days, respectively. These 3 figures are coherent because if a glass eel needs 9 days to cross the distance between E1 and E2 and 13 days between E2 and R1, it should need 22 days to cross the distance between E1 and R1.

Table II presents times of transit between the different fishing areas estimated with the cross-correlations (as shown above), distances between these fishing areas and the mean migration speed deduced from them. It has to be noted that there are two estimates (estimate 1 and estimate 2) of speed for R3 corresponding to two values of time of transit giving correlations, which do not permit to decide on a result. Most of the migration speeds range between 3 and $4 \mathrm{~km} /$ day. Migration speed between R1 and R2 (the closest fishing areas) seems to be atypical with $20.5 \mathrm{~km} /$ day.

If we take $3.5 \mathrm{~km} /$ day ( 3 to $4 \mathrm{~km} /$ day) as a result of migration speed, the glass eels cover (i) the distance between sea limit and tidal limit on Dordogne, namely $148 \mathrm{~km}$, in 42 days (37 to 49 days); (ii) the distance between sea limit and tidal limit on Garonne, namely $158 \mathrm{~km}$, in 45 days (40 to 53 days). The glass eels would thus cross the Gironde basin in about one and a half months.

\section{Efficiency of migration}

The individual-based simulator "SEGPA civelles" (LAMBERT, 2005) gives us an order of magnitude of speed of about $20.6 \mathrm{~km} /$ day for an optimal virtual glass eel which covers the distance between E1 (PK 81) and E2 (PK 46), namely $35 \mathrm{~km}$, in 1.7 days (Figure 1). The correlogram between E1 and E2 shows two significant correlations for a time of transit of 2 days and a time of transit of 9 days in 1997. A time of transit of 2 days corresponds to an STST efficiency index of 0.85 (considered close to 1 like an optimal virtual glass eel), 

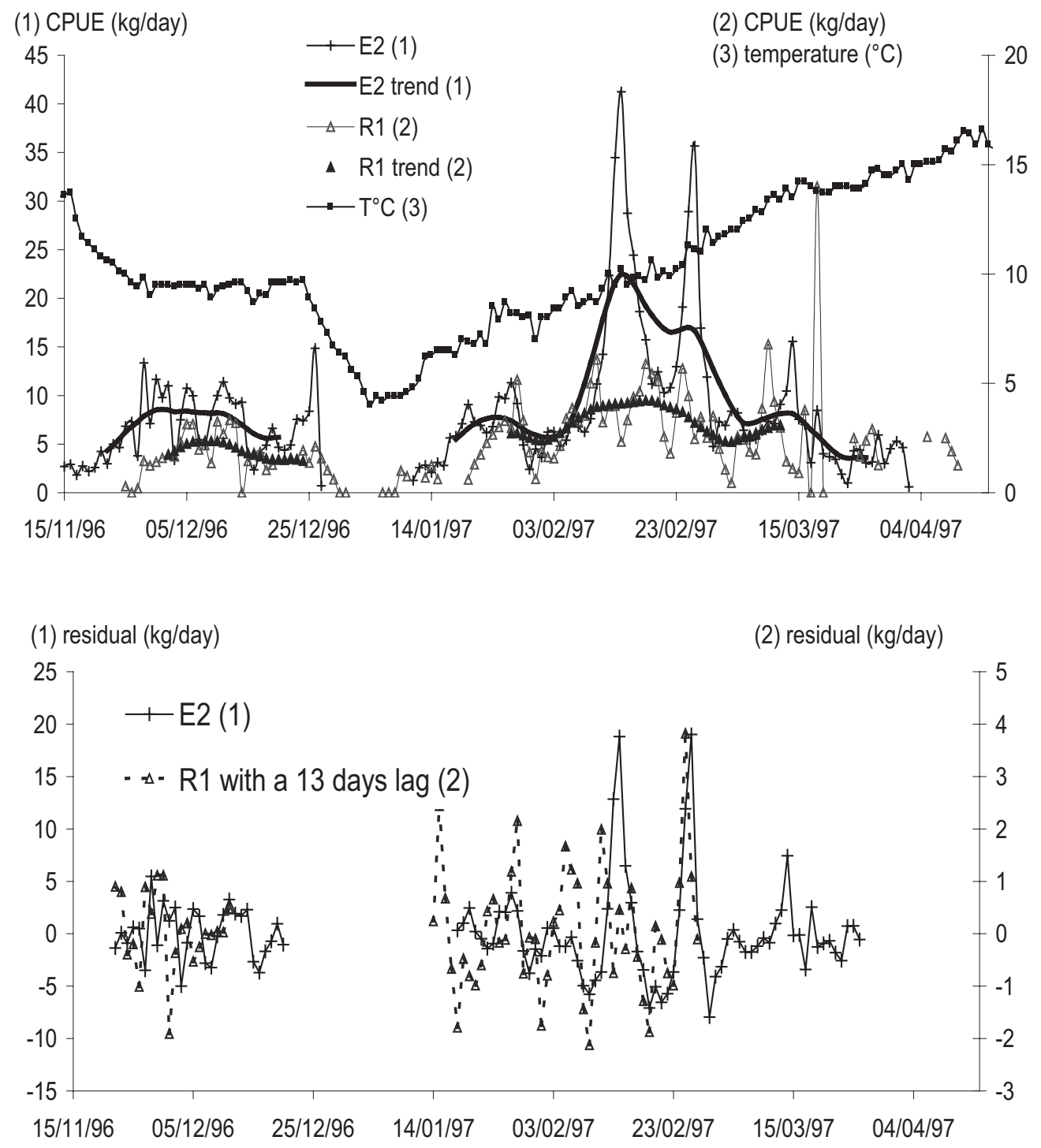

Figure 4

Examples of raw data (CPUE for areas E2 and R1 in 1997), the trends extracted from these data by a moving average, temperature in estuary (upper panel). Residuals for these series (difference between raw data and trends); the R1 series was lagged of 13 days to emphasize correlation (lower panel).

Figure 4

Exemples de données brutes (zone E2 et R1 en 1997) et les tendances qui en sont extraites par une moyenne mobile (haut). Résidus de ces séries (différences entre les données brutes et les tendances) ; la série R1 a été décalée de 13 jours pour mettre en évidence la corrélation (bas).

and a time of transit of 9 days corresponds to a STST efficiency index of 0.19 (considered lower than 1 like an underoptimal glass eel). More generally, a mean migration speed of 3 to $4 \mathrm{~km} /$ day compared with $20.6 \mathrm{~km}$ /day leads to a STST efficiency index between 0.15 to 0.19 , that means that glass eels use only $15 \%$ to $19 \%$ of possibilities offered by the flood tide current. 


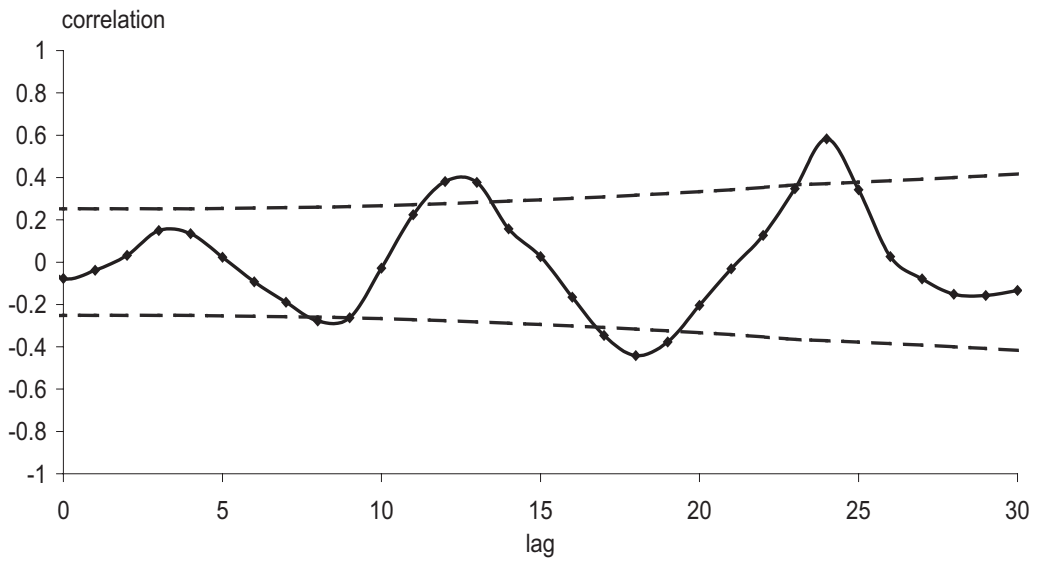

Figure 5

Cross-correllogram between E2 and R1 (solid line) series with the significance limits (dashed lines).

Figure 5

Corrélogramme croisé entre les séries E2 et R1 (trait plein) avec les limites de significativité (tiret).

Table II

Times of transit, distances and migration speed estimated by cross-correlations between different fishing areas of Gironde basin. Estimate 2 corresponds to an alternative estimate which can not be decided between estimate 1

Tableau II

Temps de transit, distances et vitesse de migration estimées par corrélations croisées entre différentes zones de pêche du bassin de la Gironde. Estimate 2 correspond à une estimation alternative du temps de transit qui n'a pas pu être départagée de estimate 1.

\begin{tabular}{|c|c|c|c|c|c|c|}
\hline \multirow{2}{*}{$\begin{array}{l}\text { Upstream } \\
\text { area }\end{array}$} & \multirow[b]{2}{*}{$\begin{array}{c}\text { Downstream } \\
\text { area }\end{array}$} & \multicolumn{2}{|c|}{ Transit time (day) } & \multirow{2}{*}{$\begin{array}{c}\text { Distance } \\
\text { (km) }\end{array}$} & \multicolumn{2}{|c|}{ Speed (km/day) } \\
\hline & & estimate 1 & estimate 2 & & estimate 1 & estimate 2 \\
\hline \multirow{4}{*}{ R3 } & E1 & 34 & 23 & 114.3 & 3.4 & 5.0 \\
\hline & E2 & 25 & 13 & 78.3 & 3.1 & 6.0 \\
\hline & E3 & 34 & 20 & 124.3 & 3.7 & 6.2 \\
\hline & E4 & 23 & 9 & 98.1 & 4.3 & 10.9 \\
\hline \multirow{4}{*}{ R1 } & E1 & 22 & & 88.0 & 4.0 & \\
\hline & E2 & 13 & & 52.0 & 4.0 & \\
\hline & E3 & 32 & & 98.0 & 3.1 & \\
\hline & E4 & 21 & & 71.8 & 3.4 & \\
\hline \multirow{5}{*}{$\mathrm{R} 2$} & $\mathrm{E} 1$ & 23 & & 108.5 & 4.7 & \\
\hline & E2 & 13 & & 72.5 & 5.6 & \\
\hline & E3 & 33 & & 118.5 & 3.6 & \\
\hline & E4 & 22 & & 92.3 & 4.2 & \\
\hline & R1 & 1 & & 20.5 & 20.5 & \\
\hline E2 & $\mathrm{E} 1$ & 9 & & 36.0 & 4.0 & \\
\hline E4 & E3 & 11 & & 26.3 & 2.4 & \\
\hline
\end{tabular}




\section{DISCUSSION}

\section{CPUE as an index of abundance}

CPUE curves presented in Figure 3 are typical symmetrical (for pibalour) and asymmetrical (for tamis) bell-shaped curves as described in GASCUEL et al. (1995). In these cases, the use of CPUE as an index of abundance appears to be valid. The pibalour curve peaks in January which is coherent with results from ELIE and ROCHARD (1994) in the Gironde estuary based on scientific survey.

\section{Migration speed}

The analysis of CPUE per tide month given by GLM is a rough method because it compares two large sectors of the Gironde basin: the Estuary and the tidal river. This migration speed however is close to the one estimated with the cross-correlations. This method seems to be appropriate when cross-correlation cannot be applied (not enough data in quantity and quality, for example). The use of delay between migration peaks has already been applied with success in the case of Allis shad (Alosa alosa) in the Gironde basin (ROCHARD, 2001) and sockeye salmon (Oncorhynchus nerka) in the Columbia River (QUINN et al., 1997).

This work highlights cross-correlations reaching 34 days between fishing areas separated by a distance of $120 \mathrm{~km}$. These results and the method used are rather original because, in literature, no estimates of migration speed for glass eels covering such a long distance exist. It will be noted however that ROCHARD (1992), who used crosscorrelations on the Gironde basin, found a lag between R3 and E1-E2 of 7 days in 1984. This lag is found neither in 1997 nor in 1999. CICCOTTI et al. (1995) used cross-correlation in the River Tiber, but their study area was only about $10 \mathrm{~km}$ long. These authors interpret lags as time of transit but they do not calculate migration speed.

Some correlations are found for both seasons (1997 and 1999), but others only for one season, maybe because of a too important noise in the time series due to the fluctuation of number of fishermen from day to day. Certainly results might be more accurate if a selection of fishermen could be done.

There are some little differences in the estimate of migration speed depending on the departure fishing area (Estuary side) and arrival fishing area (Garonne or Dordogne). To join a river (i.e. Dordogne or Garonne river) from the opposite side of the Estuary (i.e. Medoc bank -E4- or Saintonge bank -E2-), a glass eel has to cross the upper part of the Estuary and to meet with several islands, which are supposed to limit its speed.

Dyeing methods have been used to monitor batches of glass eels even if they can have some consequences on the behavior of marked glass eels. CANTRELLE (1984) demonstrated that dyes she used can partly affect the eel resistance to the current. LAMBERT et al. (in prep.) show that at least during the first hours after coloring, glass eel behavior is disturbed. After this delay, glass eel seems to recover it normal behavior. CANTRELLE (1981) has found by mark-recapture techniques (dyeing) in the Gironde basin various values of speed: from less than $1 \mathrm{~km} /$ day to $30 \mathrm{~km} /$ day (even downstream movement). Most of these values were found in the estuary for distances lower than $35 \mathrm{~km}$ corresponding to the distance between E1 and E2 (main places of release and recapture). The other values where found in the Dordogne River for a distance of more than $50 \mathrm{~km}$ with migration speeds comprised between 2 and $3.5 \mathrm{~km} /$ day. These speeds are slightly lower than those we estimated for glass eels joining the Dordogne downstream.

CANTRELLE (1981) highlights in her work that fishermen consider that glass eels needs 3 weeks to reach Libourne form the lower part of the Estuary. The migration speed deducted is about $3 \mathrm{~km} /$ day, which is of the same order of magnitude than our estimates. 
The STST efficiency index could help us to compare our results with the estimates of migration speed in different basins obtained with others methods. Unfortunately the lack of information about hydrodynamism in these basins prevents us from calculating our index. Nevertheless our estimates are of the same order of magnitude as those found in literature. For example, GASCUEL (1987a) marked glass eels by coloring in the Sèvre Niortaise. The recaptures gave migration speeds of 3 to $5 \mathrm{~km} /$ day in the experiment of march 1984 (calculated with the information found in GASCUEL, 1987b). MCCLEAVE and KLECKNER (1982) estimated that the glass eels of $A$. rostrata in the Penobscot River can migrate at 0.8 to $4.2 \mathrm{~km} /$ night. JELLYMAN and RYAN (1983) indicated a migration speed of $1.8 \mathrm{~km} /$ day into Lake Pounui for $A$. australis and $A$. dieffenbachii. Another difficulty to compare our results with other works is that the majority of the results of these studies have been obtained for a small distance and few days.

GASCUEL et al. (1995) considers that distinction between asymmetrical and symmetrical curve "is not simply linked to a delay in migration". For these authors the abundance peak in the upstream zone correspond to a natural accumulation of glass eel when the fishery is situated "at the upstream limit of the flood tide current". It is the reason for they precise that the distinction between the curves will depend on the location of the fisheries. In the Gironde basin, due to his length, the accumulation zone is situated at the extreme part of the tidal river. In the Dordogne River, EDELINE (2005) located the accumulation zone between Castillon-La-Bataille and Vignonet (20 km downstream), i.e. more than $130 \mathrm{~km}$ of the sea (20 km upstream of the end of R1 zone). To estimate migration with peak abundance method we use tamis data. Fishery data are stored by large zones (R3 for example), which didn't allow us to distinguish if the captures occur close to the tidal limit zone, or not. However a non-negligible part of catch are made in downstream zones of tidal river (R1 or R3 downstream zone). That is why the center of gravity of tamis data is localized in the middle of tidal river far away from tidal limit. For cross-correlation method, we use drossage data. Drossage is very similar to the pibalour fishing technique used in Estuary, only differing by the size and form of the net. The major part of the drossage fishery is situated in Isle river. Fishermen in this river follow migration wave beginning in Libourne area and go upstream day after day until the wave leave the authorized fishing zone.

Moreover some migration speeds are estimated between two zones of brackish water in the Estuary. Our migration speed estimates are based on the analysis of abundance seasonal peaks during a period of 23 years and on correlations between CPUE series related to fishing areas, which are several tens of kilometers apart. Temperature data (Figure 4) don't show any kind of problem due to cold water: 1999, one of our two seasons for cross-correlation analysis, has no significant cold period; after the 1997 cold period, data don't show any evidence of a prejudicial (for analysis) accumulation of glass eels.

All these facts and particular conditions in the Gironde basin allow us to exclude the hypothesis that the observed lag could correspond to the displacement of a concentration point of glass eels due to particular environmental characteristics (salted barrier, hydraulic conditions...) instead of the movement of a batch of glass eels.

\section{Efficiency of migration}

First of all, it should be noted that the STST efficiency index, being calculated with mean speeds of displacement over long distances, is not an index concerning the use of one flood tide (one tide) but a mean index concerning the use of several flood tides (many tides).

We have already reported that GASCUEL (1986; 1987a) has shown, in the Sèvre Niortaise, that only $10 \%$ of glass eels optimally use water movements (STST efficiency 
index equal to 1) and cover distances greater than the majority of glass eels (which have an index lower than 1). The only case in our work where the estimated mean speed is close to the speed of virtual optimal glass eel of "SEGPA civelles" is when glass eels go from downstream Dordogne (R1) to the Isle (R2). The estimated distance between these two fishing areas is $20.5 \mathrm{~km}$ and the estimated time of transit is 1 day. This high speed can be explained by the short distance to cover, but also by the relative inaccuracy in the estimate of the center of gravity of the data available. The center of gravity for R2 may certainly be closer to Libourne, but no more precise information can be collected. For such short distances, CANTRELLE (1981) found similar speeds. In fact at a small scale of time and space, the utilization of flood tide is very optimal: in one tide a glass eel can cross several kilometers without difficulties. That is the case here for time of transit between R1 and R2. The distance between these two zones can be covered in one flood tide. Thus the major part of glass eels will cross the zones in one day. But in the case of longer distance to cross, glass eels must use more than one tide. The longer the distance to cross, the higher the probability to miss a flood tide or to use an ebb-tide, and the lower is the migration speed. Anyway the mechanisms responsible of low speed can only express on a large scale of time and of space.

The mean migration speeds seem to be low comparatively to flood tide current (STST efficiency index range between 0.15 to 0.19). Some behavioral characteristics of glass eels, which can explain this situation, are reported from the literature. We know that glass eels mainly use flood tides to migrate (MCCLEAVE and KLECKNER, 1982; GASCUEL, 1986; WIPPELHAUSER and MCCLEAVE, 1987). However glass eels can be found in the water column during ebb tide, even if they are less numerous than during flood tide (ELIE, 1979; MCCLEAVE and KLECKNER, 1982; SHELDON and MCCLEAVE, 1985). The hypothesis that these glass eels can be carried downstream by ebb tide current cannot be excluded. It is also known that glass eels are less numerous in the water column during daytime than during night-time (GASCUEL, 1987a; ELIE and ROCHARD, 1994). This can be connected with the lucifugous behavior of glass eels (DE CASAMAJOR et al., 1999). Finally, the glass eels have more or less long phases of rest in the substratum (BARBIN and KRUEGER, 1994) which can lead them not to be present in the water column during all flood tides.

The different behaviors listed above to explain a weak efficiency do not have the same consequences for the animal. For example, let us consider the case of a glass eel that does not use every flood tide but does not go downstream and the case of a glass eel that moves sometimes downstream carried by the ebb tide current. In both cases the glass eel is under-optimal. However in the second case, the glass eel spends certainly more energy and increases its vulnerability toward fisheries. Indeed if a glass eel moves sometimes downstream, it will spent more time in water column trying to compensate this backward movement, having thus a higher probability to be caught by the fishery. In the context of declining recruitment (ICES, 2004), this behavioral question may have some important consequences in the capturability of glass eel and in the fishery mortality.

Our STST efficiency index is close to the "optimal displacement index" proposed by BERNATCHEZ and DODSON (1987). The aim is the same: to compare real speed with an optimal (theoretical) speed. However, BERNATCHEZ and DODSON (1987) judge the optimality in an energetic point of view. We think that in case of selective tidal stream transport, the optimality must be judged in relation with local hydrodynamics and swimming capacity of the animal considered. As glass eels have weak swimming capacities (TSUKAMOTO et al., 1975; MCCLEAVE, 1980), we neglect the swimming speed. If one wants to apply our STST efficiency index to a species with non-negligible swimming capacity, he should use the ratio: real migration speed divided by current speed plus swimming speed. Our index is specific to species using selective tidal stream transport. 
We have found in the literature only one recent work that has evaluated the efficiency of selective tidal stream transport. CARR et al. (2004) have tagged and tracked height blue crabs and monitored current speed. They show that crabs have an efficiency of 10 to $40 \%$ related to a passive particle (close to our concept of optimal glass eel).

\section{CONCLUSION}

The results highlight gaps that exist in the understanding of glass eel migration. It seems necessary to fill in these gaps to understand the future of glass eels (energy loss, vulnerability toward fisheries...). Our work demonstrates the interest of fishery data in biological studies, (i) which can be a good tool to estimate a migration speed even in case where telemetry and mark-recapture are inefficient; (ii) which can be used to estimate a migration speed on larger areas and longer periods of time than telemetry or markrecapture methods. We advocate for a large use of our STST efficiency index for glass eels in other basins and for other species to evaluate efficiency of selective tidal stream transport in many situations.

\section{ACKNOWLEDGEMENTS}

We thank Eric ROCHARD, Patrick LAMBERT and Isabelle ORTUSI for their help and advice and the referees for their constructive remarks.

\section{REFERENCES}

ARNOLD G.P., 1974. Rheotropism in fishes. Biological Reviews, 49, 545-576.

BARBIN G.P. and KRUEGER W.H., 1994. Behavior and Swimming Performance of Elvers of the American Eel, Anguilla-Rostrata, in an Experimental Flume. Journal of Fish Biology, 45, 1, 111-121.

BERNATCHEZ L. and DODSON J.J., 1987. Relationship between bioenergetics and behavior in anadromous fish migrations. Can. Journ. of Fish. and Aq. Sc., 44, 399407.

BERTIN L., 1951. Les anguilles. Variation, croissance, euryhalinité, toxicité, hermaphrodisme juvénile et sexualité, migrations, métamorphoses. Payot, Paris, $188 \mathrm{p}$.

CANTRELLE I., 1981. Étude de la migration et de la pêche des civelles (Anguilla anguilla L. 1758) dans l'estuaire de la Gironde. Thèse de doctorat, Paris VI, 238 p.

CANTRELLE I., 1984. Le marquage par coloration appliqué à l'étude des migrations des civelles (Anguilla anguilla, Pisces, Anguillidae). Cybium, 8, 3, 69-78.

CARR S.D., TANKERSLEY R.A., HENCH J.L., FORWARD J., RICHARD B. and LUETTICH J., RICHARD A., 2004. Movement patterns and trajectories of ovigerous blue crabs Callinectes sapidus during the spawning migration. Estuarine, Coastal and Shelf Science, 60, 567-579.

CASTELNAUD G., ROCHARD E. and LE GAT Y., 2001. Analyse de la tendance de l'abondance de l'alose Alosa alosa en Gironde à partir de l'estimation d'indicateurs halieutiques sur la période 1977-1998. Bull. Fr. Pêche Piscic., 362/363, 989-1015.

CASTONGUAY M. and GILBERT D., 1995. Effects of Tidal Streams on Migrating Atlantic Mackerel, Scomber-Scombrus L. ICES Journal of Marine Science, 52, 6, 941-954.

CICCOTTI E., RICCI T., SCARDI M., FRESI E. and CATAUDELLA S., 1995. Intraseasonal characterization of glass eel migration in the River Tiber - space and time dynamics. Journal of Fish Biology, 47, 2, 248-255. 
CREUTZBERG F., 1958. Use of tidal streams by migrating elvers (Anguilla vulgaris Turt.). Nature, 181, 357-358.

CREUTZBERG F., 1961. On the orientation of migrating elvers (Anguilla vulgaris Turt.) in a tidal area. Netherlands Journal of Sea research, 1, 3, 257-338.

DE CASAMAJOR M.N., BRU N. and PROUZET P., 1999. Influence de la luminosité nocturne et de la turbidité sur le comportement vertical de migration de la civelle d'Anguille (Anguilla anguilla L.) dans l'estuaire de l'Adour. Bull. Fr. Pêche Piscic., 355, 327-347.

DESAUNAY Y., GUÉRAULT D. and BEILLOIS P., 1987. Dynamique de la migration anadrome de la civelle (Anguilla anguilla) dans l'estuaire de la Loire: Rôle des facteurs climatiques vis-à-vis de la pêche et du recrutement in CIEM - Comité des poissons anadromes et catadromes, CM 1987/M18.

EDELINE E., 2005. Facteurs contrôlant la dispersion continentale de l'anguille européenne Anguilla anguilla. Ph D Thesis, thèse de doctorat, Cemagref/Université Paul Sabatier, Toulouse III.

ELIE P., 1979. Contribution à l'étude des montées de civelles d'Anguilla anguilla Linné (Poisson, Téléostéen, Anguilliforme), dans l'estuaire de la Loire : Pêche, Ecologie, Ecophysiologie et Elevage. Thèse de doctorat de troisième cycle, $381 \mathrm{p}$.

ELIE P. et ROCHARD E., 1994. migration des civelles d'anguilles (Anguilla anguilla L) dans les estuaires, modalités du phénomène et caractéristiques des individus. Bull. Fr. Pêche Piscic., 335, 81-98.

FORWARD R.B., TANKERSLEY R.A. and REINSEL K.A., 1998. Selective tidal stream transport of spot (Leistomus xanthurus Lacepede) and pinfish (Lagodon rhomboides (Linnaeus)) larvae: Contribution of circatidal rhythms in activity. Journal of Experimental Marine Biology and Ecology, 226, 1, 19-32.

FORWARD R.B., TANKERSLEY R.A. and POCHELON P.N., 2003. Circatidal activity rhythms in ovigerous blue crabs, Callinectes sapidus: implications for ebb-tide transport during the spawning migration. Marine Biology, 142, 1, 67-76.

GASCUEL D., 1986. Flow-carried and active swimming migration of the glass eel (Anguilla anguilla) in a tidal area of a small estuary on the French Atlantic coast. Helgolaender Meeresuntersuchungen, 40, 321-326.

GASCUEL D., 1987a. La civelle d'anguille dans l'estuaire de la Sèvre Niortaise : biologie, écologie, exploitation. Ecole Nationale Supérieure Agronomique de Rennes, Rennes, 327 p.

GASCUEL D., 1987b. La civelle d'anguille dans l'estuaire de la Sèvre Niortaise : biologie, écologie, exploitation. Ecole Nationale Supérieure Agronomique de Rennes, Rennes, $204 \mathrm{p}$.

GASCUEL D., FEUNTEUN E. and FONTENELLE G., 1995. Seasonal dynamics of estuarine migration in glass eels (Anguilla anguilla). Aquatic Living Resources, 8, 123-133.

GIBSON R.N., 1997. Behaviour and the distribution of flatfishes. Journal of Sea Research, 37, 3-4, 241-256.

ICES, 2004. Report of the ICES/EIFAC Working Group on Eels. ICES CM 2004/ACFM:09, $207 \mathrm{p}$.

JELLYMAN D.J. and RYAN C.M., 1983. Seasonal migration of elvers (Anguilla spp.) into Lake Pounui, New Zealand, 1974-1978. New Zealand Journal of Marine and Freshwater Research, 17, 1-15. 
LAMBERT P., 2005. Exploration multiscalaire des paradigmes de la dynamique de la population d'anguilles européennes à l'aide d'outils de simulation. Thèse de doctorat, Université Bordeaux 1, $219 \mathrm{p}$.

LAMBERT P., BARDONNET A., ROQUEPLO C., BOLLIET V., BEAULATON L. and HUCHET E., in prep. Impact du marquage au rouge neutre et à la rhodamine sur l'activité de déplacement des civelles d'anguille.

LEGENDRE L. and LEGENDRE P., 1979. Ecologie numérique : Tome 2 : la structure des données écologiques. Masson, Paris, 247 p.

LOWE R.H., 1950. Factors influencing the runs of elvers in the river Bann, Northern Ireland. Journal du conseil. Conseil International pour l'Exploration de la Mer, 17, 3, 299 315.

MCCLEAVE J.D., 1980. Swimming performance of European eel (Anguilla anguilla (L.)) elvers. Journal of Fish Biology, 16, 445-452.

MCCLEAVE J.D. and KLECKNER R.C., 1982. Selective tidal stream transport in the estuarine migration of glass eels of the American eel (Anguillla rostrata). Journal du Conseil International pour l'Exploration de la Mer, 40, 262-271.

MCCLEAVE J.D. and WIPPELHAUSER G.S., 1987. Behavioral aspects on selective tidal stream transport in juvenile American eels. American Fisheries Society Symposium, 1, 138-150.

QUINN T.P., HODGSON S. and PEVEN C., 1997. Temperature, flow, and the migration of adult sockeye salmon (Oncorhynchus nerka) in the Columbia River. Can. Journ. of Fish. and Aq. Sci., 54, 6, 1349-1360.

ROCHARD E., 1992. Mise au point d'une méthode de suivi de l'abondance des amphihalins dans le système fluvio-estuarien de la Gironde, application à l'étude écobiologique de l'esturgeon Acipenser sturio. Thèse de doctorat, Université de Rennes I, 296 p.

ROCHARD E., 2001. Migration anadrome estuarienne des géniteurs de grande alose Alosa alosa, allure du phénomène et influence du rythme des marées. Bull. Fr. Pêche Piscic., 362/363, 853-867.

SAS, 2000. SAS OnlineDoc, Version 8. SAS Institute Inc.

SCHMIDT J., 1906. Contributions to the life-history of the eel (Anguilla vulgaris, Flem.). Rapports et procés-verbaux des réunions. Conseil Internatinal pour l'Exploration de la Mer, vol. 5, 137-274.

SHELDON M.R. and MCCLEAVE J.D., 1985. Abundance of glass eels of the American eel Anguilla rostrata, in mid-channel and near shore during estuarine migration. Naturaliste Canadien, 112, 425-430.

SHERIDAN P.F. and CASTRO MELENDEZ R.G., 1990. Determining movement patterns in marine organisms: comparison of methods tested on penaeids shrimp in PARKER N.C., GIORGI A.E., HEIDINGER R.C., JESTER D.B., PRINCE E.D. and WINANS G.A. (eds.), Proceedings from the International Symposium and Educational Workshop on Fish-Marking Techniques, Seattle, Symposium 7, 604-612.

SORENSEN P.W. and BIANCHINI M., 1986. Environmental correlates of the freshwater migration of elvers of the American eel in the Rhode Island Brook. Transactions of the American Fisheries Society, 115, 258-268. 
THORSTAD E.B., FLEMING I.A. and NAESJE T.F. editors, 2002. Aquatic telemetry. Proceedings of the Fourth Conference on Fish telemetry in Europe, Kluwer Academic Publishers, $292 \mathrm{p}$.

TSUKAMOTO K., KAJHARA T. and M.N., 1975. Swimming ability of fish. Bulletin of the Japanese Society of the Scientific Fisheries, 41, 2, 167-174.

TZENG W.N., 1984. Dispersal an upstream migration of marked Anguillid eel, Anguilla japonica, elvers in the Estuary of the Shuang River, Taiwan. Bulletin of the Japanese Society of Fisheries Oceanography, 45, 10-19.

WEIHS D., 1978. Tidal stream transport as an efficient method for migration. Journal $d u$ Conseil International pour l'Exploration de la Mer, 38, 92-99.

WIPPELHAUSER G.S. and MCCLEAVE J.D., 1987. Precision of behavior of migrating juvenile American eels (Anguilla rostrata) utilizing selective tidal stream transport. Journal du Conseil International pour l'Exploration de la Mer, 44, 80-89. 
